This item was submitted to Loughborough's Research Repository by the author.

Items in Figshare are protected by copyright, with all rights reserved, unless otherwise indicated.

\title{
Psychological distress and infectious disease mortality in the general population
}

PLEASE CITE THE PUBLISHED VERSION

https://doi.org/10.1016/j.bbi.2018.12.011

\section{PUBLISHER}

(C) Elsevier

\section{VERSION}

AM (Accepted Manuscript)

\section{PUBLISHER STATEMENT}

This paper was accepted for publication in the journal Brain, Behavior, and Immunity and the definitive published version is available at https://doi.org/10.1016/j.bbi.2018.12.011

\section{LICENCE}

CC BY-NC-ND 4.0

\section{REPOSITORY RECORD}

Hamer, Mark, Mika Kivimaki, Emmanuel Stamatakis, and G. David Batty. 2019. "Psychological Distress and Infectious Disease Mortality in the General Population". figshare. https://hdl.handle.net/2134/36513. 


\section{Psychological distress and infectious disease mortality in the general population}

Mark Hamer, ${ }^{1,2}$ Mika Kivimaki, ${ }^{2}$ Emmanuel Stamatakis, ${ }^{2,3,4}$ G David Batty, ${ }^{2}$

${ }^{1}$ School of Sport, Exercise and Health Sciences, Loughborough University, Loughborough, United Kingdom.

${ }^{2}$ Department of Epidemiology and Public Health, University College London, London, United Kingdom.

${ }^{3}$ Charles Perkins Centre Epidemiology Unit, University of Sydney, Sydney, Australia.

${ }^{4}$ Prevention Research Collaboration, School of Public Health, University of Sydney, Sydney, Australia.

Correspondence: Professor Mark Hamer, Loughborough University, Loughborough LE11 3TU, United Kingdom. Phone: +44 (0) 1509 228473. Email: m.hamer@lboro.ac.uk

Running head: Psychological distress and infectious disease

Word count: 2,309

Disclosures: None of the authors have any competing interests to declare. 


\section{Abstract}

There is a paucity of studies examining the relation between high psychological distress and infectious disease in the general population. We examined this association in a large multicohort study drawn from the general population. The analytic sample comprised 104,923 men and women (age, $47.3 \pm 17.4 \mathrm{yr} ; 45.7 \%$ men) in which psychological distress symptoms was assessed using the 12-item version of the General Health Questionnaire. There were 1,535 deaths attributed to infectious diseases during 971,220 person-years of follow up (mean 9.3; range 0.1 - 17.1yrs). A dose-response association between GHQ-12 score and all infectious disease mortality was observed after adjusting for age, sex, survey year, occupational social class, longstanding illness, smoking, alcohol, and physical activity (per SD increase, hazard ratio $=1.24 ; 95 \% \mathrm{Cl}, 1.20-1.28)$. A similar pattern was apparent for viral infections $(1.23 ; 1.14,1.33)$ and pneumonia $(1.20 ; 1.13,1.28)$, but weaker for bacterial infections $(1.09 ; 1.00,1.19)$. In conclusion, psychological distress is associated with higher risk of infectious disease.

Key words: Depression; bacterial infections; virus diseases; mortality 


\section{Introduction}

Life threatening infections affect more than 19 million people each year (Fleischmann et al., 2016). Efforts to identify potential risk factors for such diseases has traditionally focused on biological, social, and environmental indices, with rather less consideration having been given to the aetiological role of psychological characteristics such as cognition, stress, and personality. Higher levels of psychological distress (depression and anxiety) are thought to impair various aspects of both innate and adaptive immunity. Early experiments found that individuals with psychological stress had an increased risk of acute infectious respiratory illness after administration of nasal drops containing respiratory viruses and slowing of wound healing after undergoing a standardised $3.5 \mathrm{~mm}$ punch biopsy wound (Cohen et al., 1991; Kiecolt-Glaser et al., 1995). In studies in which investigators sampled people responsible for the care of an elderly spouse (as a model of chronic stress), blunted responses to vaccines, impaired control of latent viruses, exaggerated release of inflammatory cytokines, and accelerated cellular aging are evident (Gouin et al., 2008). Some data also suggest depressive symptoms are an adaptive response to pre-clinical disease, which promotes pathogen host defence through immunological and behavioural changes (Raison \& Miller, 2013). Increases in negative mood, for example, can be induced experimentally through vaccination (Wright et al., 2005). The link between depression and increased systemic inflammation may also stem from inflammation in the absence of pathogens (i.e., sterile inflammation) (Fleshner et al., 2017) although evidence in this area is equivocal.

Existing data on psychological distress and infectious disease in the general population is sparse (Andersson et al., 2016), with the majority of work having focused on specific groups (e.g., caregivers, elderly) or small scale experimental work (Gouin et al., 2008). The aim of 
our study was to examine the association of psychological distress with infection-related mortality in a non-clinical general population sample.

\section{Methods}

\section{Participants}

The Health Survey for England (HSE) and the Scottish Health Survey (SHS) are general population-based surveillance studies (Mindell et al., 2012). Participants herein took part in one of the following surveys: 1994 (HSE only), 1995 (SHS only), 1997 (HSE only), 1998 (HSE and SHS), 1999 (HSE only), 2003 (HSE and SHS), 2004, 2006, 2008 (HSE only). In all, $91.4 \%$ of participants gave consent to prospective linkage with mortality records.

\section{Psychological distress}

The 12-item version of the General Health Questionnaire (GHQ-12) was used to measure psychological distress - higher scores (range 0-12) indicate greater distress - and has been validated against standardised psychiatric interviews for depression and anxiety (Aalto et al., 2012). More than 3 points on the GHQ-12 is indicative of psychological distress (Aalto et al., 2012). Consistent with our previous analyses (Russ et al., 2012) we divided people into four groups: asymptomatic (score 0), sub clinically symptomatic (1-3), symptomatic (4-6), and highly symptomatic (7-12).

\section{Covariates}

The questionnaire used to assess physical activity captures frequency, intensity, and duration and has reasonable validity and reliability (Scholes et al., 2014). Based on the current guidelines (at least $150 \mathrm{~min} /$ week moderate to vigorous physical activity [MVPA]; 
World Health Organization, 2010), participants were categorised as inactive (not reporting any MVPA), insufficiently active ( $>0<150 \mathrm{~min} /$ week MVPA), or sufficiently active (at least 150 min/week MVPA). Participants were asked if they had regularly smoked a cigarette, a cigar or a pipe, and if so whether they were current smokers. Current smokers were asked to quantify the number of cigarettes a day they smoked. Smoking status was finally categorised into 5 groups (never; ex-smoker; current <10/d; current $10-20 / d$; current $>20 / d$ ). Selfreported smoking has been previously validated in the present sample against objective salivary cotinine data (Person's correlation 0.78 [p<0.001]), (Hamer et al., 2010).

Participants were asked if they drank alcohol nowadays, and those who said not were categorised as 'never' drinker or 'ex-drinker' if they used to drink and had stopped. Drinkers were asked, "How often have you had an alcoholic drink of any kind during the last 12 months?" and categorised as < monthly, $1-2$ / month, $1-4$ /week, $\geq 5$ /week. Health status was assessed by asking participants whether they had 'any longstanding illness, disability of infirmity,' and transformed into a binary variable (yes/no). Socioeconomic status assessed using the Registrar General's classification: professional and managerial occupations; skilled, non-manual occupations; skilled manual occupations; and, routine and manual occupations.

\section{Ascertainment of mortality}

Participants were flagged using the procedures of the UK National Health Service Central Registry. Diagnoses for the primary cause of death were based on the International Classification of Diseases, Ninth (ICD-9) and Tenth (ICD-10) Revisions. Codes corresponding to infectious diseases were 001- 139 and 480-488 for ICD9 and A00-B99 and J09-J18 for ICD10. We further sub-typed the outcome into bacterial or viral infections, and pneumonia (as the organism was unspecified in all our cases). 


\section{Statistical analysis}

Cox proportional hazards regression was used to compute hazard ratios with accompanying $95 \%$ confidence intervals to summarise the association between psychological distress and risk of infectious disease mortality. For participants who survived, the data were censored up to the end of 2009 (SHS) or the first quarter of 2011 (HSE). The timescale was calendar time (months). Effect estimates were adjusted for age, sex, survey year, occupational social class, longstanding illness, smoking, alcohol, and physical activity. All analyses were performed using SPSS version 22 (IBM Inc.).

\section{Results}

The analytic sample comprised 104,923 men and women (age, 47.3 $\pm 17.4 \mathrm{yrs} ; 45.7 \%$ men). Fifteen percent of the sample reported psychological distress. There were 1,535 deaths attributed to infectious diseases during 971,220 person-years of follow up (mean 9.3; range $0.1-17.1 \mathrm{yrs})$. As expected, participants that died from infectious diseases were older, more likely to be ex-smokers, physically inactive, report longstanding illnesses, and come from lower occupational social classes (Table 1).

A dose-response association between psychological distress and all infectious disease mortality was observed (Figure 1), and increased risk was detected even at moderately low levels of distress: hazard ratio (HR) for distress score $1-3=1.28 ; 95 \% \mathrm{Cl}, 1.14-1.45$ compared to those without any such symptoms. The highest risk was apparent in the most distressed study members such that people with a distress score of 7-12 experienced an approximately 2 fold increased risk ( $p[$ trend $]=0.001$ ). A similar pattern was observed for viral infections and pneumonia, while the results for bacterial infection did not follow a linear pattern. 
Sensitivity analyses

We repeated the analysis after removing deaths in the first 2 years of follow-up (351 infectious disease events removed) in order to explore reverse causality. This is standard practice in epidemiological analyses and is based on the rationale that study members with symptoms of serious infectious disease which are hidden at study entry, but which nonetheless may raise their distress scores, will die in the early stages of follow-up. Following these analyses, our results were unchanged (HR for GHQ-12 >6 $=1.67 ; 95 \% \mathrm{Cl}$, $1.37-2.04)$

Since psychological distress was more prevalent in smokers $(19.4 \%)$ compared with never smokers $(13.2 \%)$ we re-analysed the relation of distress with pneumonia after stratifying the sample by smoking status. This strategy allowed us to remove the potential confounding effect of smoking. Similar patterns emerged between psychological distress and risk of pneumonia in each smoking group (never smokers, former, current smokers) (Table S1).

Finally, given the large discrepancy in age between survivors and those dying from infectious diseases, we restricted the analyses to participants aged $70 \mathrm{yr}$ and above. Again, this had no meaningful impact on the results (Table S2).

\section{Discussion}

Our findings demonstrate a dose-response association between symptoms of psychological distress and risk of infectious disease mortality. In the most distressed study members, doubling of the risk of death from viral infections. Smokers often demonstrate higher levels of distress (Kassel et al., 2003), and smoking itself produces an unfavourable inflammatory response, however, the association between distress and risk of pneumonia persisted in 
never smokers. Thus our results are unlikely to be explained by confounding effects of smoking.

In previously published work we have examined associations between psychological distress and other causes of mortality; For instance, per standard deviation increase in distress (GHQ-12) score, after adjustment for age and sex we have reported increases of $21 \%$ in risk of all-cause mortality, $22 \%$ in risk of cardiovascular disease death, $9 \%$ in risk of cancer death, and $26 \%$ in risk of death from external causes (Russ et al., 2012). These results are comparable to the infectious disease outcome reported here (per SD increase distress, HR= $1.24 ; 1.20-1.28)$. Since psychological distress is associated with a wide range of non-specific outcomes one might interpret this in several ways. Firstly, observed associations may be non-causal and instead explained by reverse causation; indeed some data indicate that depressive symptoms promote pathogen host defence responses (Raison \& Miller, 2013) suggesting that psychological symptoms may develop in response to early pre-clinical stages of disease. Nevertheless, when we removed deaths occurring in the first 2 years of follow up the results remained largely unchanged. Secondly, psychological distress may directly affect a number of different biological pathways and influence health status by diverse mechanisms. Indeed, associations between stress and infectious disease mortality seem biologically plausible based on existing evidence (Bauer et al., 2009).

In the present study, psychological distress was only assessed on one occasion at baseline, thus we can only speculate about chronicity of exposure. There is evidence, however, that rates of recurrence are high for psychological distress (Jokela et al., 2011). Recent data showed that the risk of infection increased following a single occurrence of depression but was elevated further with multiple depressive episodes (Andersson et al., 2016). Although the GHQ-12 has been validated against standardised psychiatric interviews it remains a self- 
report instrument that is not diagnostic of anxiety or depression. These points notwithstanding, there is a reasonably high correlation between high scores on the GHQ-12 scale and diagnosed depression as ascertained from standard clinical interview (Aalto et al., 2012). Health status was assessed using self-report. Single item questions on health are widely used across surveys and demonstrate validity against objective measures (eg, Pierce et al., 2009). Also, in the present study longstanding illness was associated with higher risk of mortality $(\mathrm{HR}=1.46,95 \% \mathrm{Cl}, 1.30-1.65)$ further validating the variable as a reliable indicator of health status. 


\section{References}

Aalto AM, Elovainio M, Kivimäki M, Uutela A, Pirkola S. The Beck Depression Inventory and General Health Questionnaire as measures of depression in the general population: A validation study using the Composite International Diagnostic Interview as the gold standard. Psychiatry Res. 2012; 197:163-71.

Andersson NW, Goodwin RD, Okkels N, Gustafsson LN, Taha F, Cole SW, MunkJørgensen P. Depression and the risk of severe infections: prospective analyses on a nationwide representative sample. Int J Epidemiol. 2016;45(1):131-9.

Bauer ME, Jeckel CM, Luz C. The role of stress factors during aging of the immune system. Ann N Y Acad Sci. 2009 Feb;1153:139-52.

Cohen S, Tyrrell DA, Smith AP. Psychological stress and susceptibility to the common cold. N Engl J Med. 1991;325(9):606-12.

Fleischmann C, Scherag A, Adhikari NKJ, et al; International Forum of Acute Care Trialists. Assessment of global incidence and mortality of hospital-treated sepsis: current estimates and limitations. Am J Respir Crit Care Med. 2016;193(3):259-272.

Fleshner M, Crane CR. Exosomes, DAMPs and miRNA: features of stress physiology and immune homeostasis. Trends Immunol. 2017;38: 768-776.

Gouin JP, Hantsoo L, Kiecolt-Glaser JK. Immune dysregulation and chronic stress among older adults: a review. Neuroimmunomodulation. 2008;15(4-6):251-9.

Hamer M, Stamatakis E, Kivimaki M, Lowe GD, Batty GD. Objectively measured secondhand smoke exposure and risk of cardiovascular disease: what is the mediating role of inflammatory and hemostatic factors? J Am Coll Cardiol 2010;56: 18-23. 
Jokela M, Singh-Manoux A, Shipley MJ, Ferrie JE, Gimeno D, Akbaraly TN, Head J, Elovainio M, Marmot MG, Kivimäki M. Natural course of recurrent psychological distress in adulthood. J Affect Disord. 2011;130(3):454-61.

Kassel JD, Stroud LR, Paronis CA. Smoking, stress, and negative affect: correlation, causation, and context across stages of smoking. Psychol Bull 2003;129 (2) 270- 304

Kiecolt-Glaser JK, Marucha PT, Malarkey WB, Mercado AM, Glaser R. Slowing of wound healing by psychological stress. Lancet. 1995;346(8984):1194-6.

Mindell J, Biddulph JP, Hirani V, Stamatakis E, Craig R, Nunn S, Shelton N. Cohort profile: the health survey for England. Int J Epidemiol. 2012;41(6):1585-93.

Pierce MB, Zaninotto P, Steel N, Mindell J. Undiagnosed diabetes-data from the English longitudinal study of ageing. Diabet Med 2009;26: 679-685.

Raison $\mathrm{CL}$, Miller $\mathrm{AH}$. The evolutionary significance of depression in Pathogen Host Defense (PATHOS-D). Mol Psychiatry. 2013;18(1):15-37.

Russ TC, Stamatakis E, Hamer M, Starr JM, Kivimäki M, Batty GD. Association between psychological distress and mortality: individual participant pooled analysis of 10 prospective cohort studies. BMJ. 2012;345:e4933.

Scholes S, Coombs N, Pedisic Z, et al. Age- and sex-specific criterion validity of the health survey for England Physical Activity and Sedentary Behavior Assessment Questionnaire as compared with accelerometry. Am J Epidemiol. 2014;179(12):1493-1502.

World Health Organisation. Global recommendations on physical activity for health. 2010; www.who.int/dietphysicalactivity/publications/9789241599979/en/. Accessed February 2018.

Wright CE, Strike PC, Brydon L, Steptoe A. Acute inflammation and negative mood: mediation by cytokine activation. Brain Behav Immun. 2005;19(4):345-50. 
Table 1. Baseline characteristics according to death status

\begin{tabular}{|c|c|c|c|}
\hline Variable at baseline & Alive & $\begin{array}{l}\text { Death from other } \\
\text { causes }\end{array}$ & $\begin{array}{l}\text { Death from } \\
\text { infectious disease }\end{array}$ \\
\hline $\mathrm{N}$ & 94618 & 8770 & 1535 \\
\hline Age (yrs, SD) & $45.0 \pm 16.2$ & $67.8 \pm 13.3$ & $74.1 \pm 10.9$ \\
\hline Sex (\% men) & 45.1 & 51.4 & 50.2 \\
\hline $\begin{array}{l}\text { Smokers (\%) } \\
\text { Never } \\
\text { Ex-smoker } \\
\text { Light, }<10 / d \\
\text { Medium,10-19/d } \\
\text { Heavy, } \geq 20 / d \\
\end{array}$ & $\begin{array}{l}49.4 \\
23.9 \\
7.5 \\
10.9 \\
8.4 \\
\end{array}$ & $\begin{array}{l}32.8 \\
39.2 \\
5.6 \\
10.4 \\
12.0 \\
\end{array}$ & $\begin{array}{l}32.5 \\
45.5 \\
7.2 \\
8.1 \\
6.8 \\
\end{array}$ \\
\hline $\begin{array}{l}\text { Alcohol, frequency (\%) } \\
\text { Never } \\
\text { Ex-drinker } \\
<\text { monthly } \\
1-2 \text { / month } \\
1-4 \text { /week } \\
\geq 5 \text { /week }\end{array}$ & $\begin{array}{l}6.1 \\
3.7 \\
13.9 \\
13.3 \\
45.9 \\
17.0 \\
\end{array}$ & $\begin{array}{l}7.3 \\
8.6 \\
18.1 \\
10.2 \\
32.5 \\
23.2 \\
\end{array}$ & $\begin{array}{l}9.7 \\
10.1 \\
20.3 \\
9.0 \\
27.8 \\
23.0\end{array}$ \\
\hline $\begin{array}{l}\text { Physical activity (\%) } \\
\text { Inactive } \\
\text { Insufficiently active } \\
\text { Sufficiently active }\end{array}$ & $\begin{array}{l}48.5 \\
29.1 \\
22.4\end{array}$ & $\begin{array}{l}82.4 \\
11.6 \\
6.1\end{array}$ & $\begin{array}{l}88.1 \\
8.1 \\
3.8\end{array}$ \\
\hline GHQ-12 score & $1.4 \pm 2.6$ & $1.9 \pm 3.0$ & $2.0 \pm 3.0$ \\
\hline $\begin{array}{l}\text { Longstanding illnesses } \\
(\%)\end{array}$ & 41.5 & 69.6 & 74.9 \\
\hline $\begin{array}{l}\text { Occupational social class } \\
\text { Professional (\%) } \\
\text { Managerial } \\
\text { Skilled } \\
\text { Semi-skilled } \\
\text { Unskilled } \\
\text { Other (armed forces, etc) }\end{array}$ & $\begin{array}{l}4.9 \\
28.3 \\
42.9 \\
17.6 \\
5.7 \\
0.5\end{array}$ & $\begin{array}{l}3.1 \\
21.9 \\
45.4 \\
19.2 \\
9.9 \\
0.5\end{array}$ & $\begin{array}{l}2.0 \\
19.5 \\
46.3 \\
21.0 \\
10.3 \\
0.9\end{array}$ \\
\hline
\end{tabular}


Figure 1 caption.

The association between psychological distress and infectious disease mortality $(\mathrm{N}=104,923)$. Effect estimates are adjusted for age, sex, longstanding illness, occupational social class, physical activity, smoking, alcohol, survey year. 


\begin{tabular}{|c|c|c|c|c|c|}
\hline $\begin{array}{l}\text { Cause of death } \\
\text { GHQ-12 score }\end{array}$ & $\mathrm{N}$ (deaths) & $\mathrm{N}$ (total) & $\begin{array}{c}\text { Hazard ratio } \\
(95 \% \mathrm{Cl})\end{array}$ & $\begin{array}{c}\text { Hazard ratio } \\
(95 \% \mathrm{Cl})\end{array}$ & $\begin{array}{l}\mathrm{P} \text { for } \\
\text { trend }\end{array}$ \\
\hline \multicolumn{6}{|l|}{ All infections } \\
\hline 0 (Reference) & 742 & 62,700 & 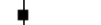 & 1.00 (Reference) & \\
\hline $1-3$ & 459 & 26,269 & $\rightarrow-$ & $1.27(1.13-1.43)$ & \\
\hline $4-6$ & 170 & 8313 & & $1.60(1.35-1.90)$ & \\
\hline $7-12$ & 164 & 7647 & & $1.67(1.40-1.98)$ & $<0.001$ \\
\hline \multicolumn{6}{|c|}{ Bacterial infections } \\
\hline 0 (Reference) & 219 & 62,700 & & 1.00 (Reference) & \\
\hline $1-3$ & 121 & 26,269 &. & $1.17(0.93-1.46)$ & \\
\hline $4-6$ & 51 & 8313 & & $1.61(1.18-2.20)$ & \\
\hline $7-12$ & 37 & 7647 & & $1.23(0.86-1.76)$ & 0.025 \\
\hline \multicolumn{6}{|l|}{ Viral infections } \\
\hline 0 (Reference) & 174 & 62,700 & 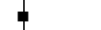 & 1.00 (Reference) & \\
\hline $1-3$ & 132 & 26,269 & $\because$ & $1.49(1.19-1.88)$ & \\
\hline $4-6$ & 47 & 8313 & & $1.71(1.23-2.37)$ & \\
\hline $7-12$ & 53 & 7647 & & $2.14(1.56-2.93)$ & $<0.001$ \\
\hline \multicolumn{6}{|l|}{ Pneumonia } \\
\hline 0 (Reference) & 349 & 62,700 & & 1.00 (Reference) & \\
\hline $1-3$ & 206 & 26,269 &. & $1.24(1.04-1.48)$ & \\
\hline $4-6$ & 72 & 8313 & & $1.60(1.23-2.06)$ & \\
\hline \multirow[t]{2}{*}{$7-12$} & 74 & 7647 & & $1.83(1.42-2.37)$ & $<0.001$ \\
\hline & & & & & \\
\hline
\end{tabular}




\section{Supplementary material}

Table S1. The association between psychological distress and pneumonia mortality stratified by smoking status $(N=104,923)$

\begin{tabular}{|l|l|l|l|}
\hline $\begin{array}{l}\text { Psychological } \\
\text { distress (GHQ-12 } \\
\text { score) }\end{array}$ & $\begin{array}{l}\text { Never smoker } \\
(\mathrm{N}=50,105 ;\end{array}$ & $\begin{array}{l}\text { Ex-smoker } \\
(\mathrm{N}=26,724 ; \\
238 \text { events })\end{array}$ & $\begin{array}{l}\text { Current smoker } \\
(\mathrm{N}=28,094 ; \\
148 \text { events })\end{array}$ \\
\hline 0 (no distress) & $1.00($ Ref $)$ & 1.00 & 1.00 \\
\hline $1-3$ & $1.18(0.88,1.59)$ & $1.26(0.97,1.64)$ & $1.29(0.87,1.90)$ \\
\hline $4-6$ & $1.23(0.77,1.97)$ & $2.00(1.37,2.91)$ & $1.50(0.86,2.61)$ \\
\hline $7-12$ & $1.74(1.10,2.77)$ & $1.96(1.32,2.91)$ & $1.83(1.10,3.04)$ \\
\hline
\end{tabular}

Hazard ratios are adjusted for age, sex, longstanding illness, occupational social class, physical activity, alcohol survey year. 
Table S2. The association between psychological distress and infectious disease mortality in participants aged 70 yrs and above excluding events in first year of follow-up $(\mathrm{N}=12,838)$

\begin{tabular}{|c|c|c|c|c|c|}
\hline $\begin{array}{l}\text { Psychological } \\
\text { distress (GHQ-12 } \\
\text { score) }\end{array}$ & $\mathbf{N}$ & $\begin{array}{l}\text { HR (95\% CI) } \\
\text { All infections } \\
\text { (1000 events) }\end{array}$ & $\begin{array}{l}\text { HR }(95 \% \text { Cl) } \\
\text { Bacterial infections } \\
\text { (233 events) }\end{array}$ & $\begin{array}{l}\text { HR ( } 95 \% \text { Cl) } \\
\text { Viral infections } \\
\text { (262 events) }\end{array}$ & $\begin{array}{l}\text { HR (95\% CI) } \\
\text { Pneumonia } \\
\text { (495 events) }\end{array}$ \\
\hline 0 (no distress) & 7662 & 1.00 (Ref) & 1.00 & 1.00 & 1.00 \\
\hline $1-3$ & 3395 & $1.26(1.09,1.45)$ & $1.11(0.82,1.51)$ & $1.59(1.20,2.10)$ & $1.15(0.94,1.42)$ \\
\hline $4-6$ & 964 & $1.66(1.35,2.05)$ & $1.72(1.14,2.59)$ & $1.79(1.20,2.67)$ & $1.64(1.21,2.21)$ \\
\hline $7-12$ & 822 & $1.59(1.27,2.00)$ & $1.15(0.68,1.93)$ & $2.16(1.44,3.22)$ & $1.53(1.09,2.13)$ \\
\hline$p$-trend & & $<0.001$ & 0.078 & $<0.001$ & $<0.001$ \\
\hline
\end{tabular}

Effect estimates are adjusted for age, sex, longstanding illness, occupational social class, physical activity, smoking, alcohol, survey year. 